\title{
Bank management in bank decline: Bank mergers as a recovery recipe? ${ }^{\triangleleft}$
}

\author{
Anders Kjellman ${ }^{a^{*}}$, Risto Tainio ${ }^{\mathrm{b}}$, Taisto Kangas ${ }^{\mathrm{b}}$ \\ a Novia University of Applied Science, Vaasa, Finland. \\ ${ }^{\mathrm{b}}$ Aalto University, Helsinki, Finland. \\ *Corresponding author's email address: anders.kjellman@parnet.fi
}

\section{H I G H L I G H T S:}

1. We find that decline in banking cannot be understood without looking at growth before decline.

2. Based on 309 Finnish bank mergers during 1990 to 2013, we found that many bank managers gradually lost their confidence concerning their capability of successfully running their banks, thus choosing to merge.

3. Mergers have been useful as a mean for continuation of banking activity. However, the Finnish evidence points to the fact that banks that don't merge will perform better than banks that are involved in merger processes.

4. Finally, we have developed a model for explaining bank mergers as a way out from crisis situations.

\section{Article History}

Received: 28-11-2014

Accepted: 15-12-2014

Available online: 23-12-2014

Keywords:

Banking crisis;

Bank management;

Decline model;

Merger.

JEL Classification:

G01; G02; G34.

(C) 2014 The Authors. This is an open access article under the terms of the Creative Commons Attribution License 4.0, which allows use, distribution and reproduction in any medium, provided the original work is properly cited.

\subsection{Introduction}

Bank management in a recession is a difficult task and unfortunately there is no obvious strategy recipe available for management dealing with decline. During the ongoing global financial crises Tourish and Harigie (2012) argue that bank managers say that they are pressured, passive observers of events and victims during the decline stages. Based on our evidence we argue that management in decline is much more complex, than previous research has indicated. We therefore saw a clear need to further explore the relationship between bank decline and bank mergers.

The main aim of this paper is to build a model of bank management during a decline period. Thereby we are investigating bank mergers as a recovery recipe. Our findings based on the bank market in Finland during the time period 1990-2013 indicate that the managerial motives behind mergers vary and are crisis dependent. Our data

\footnotetext{
$\diamond$ The authors are most grateful for the discussions with and help received by managers of former or still existing banks. Financial support from the Liikesivistysrahasto is gratefully acknowledged.
} 
indicates that most mergers occur during an economic downturn. Our model is based on Weitzel and Jonssons (1989) and Collins' (2009) decline models. However, adapted to suit the banking industry. We found six stages in the decline process of banks. The first pre-stage of bank decline is in fact a little contradictory, because we found a period of rapid growth before the decline phase starts. Growth seems to breed the seeds of decline in the financial industry. In the first decline stage the bank management is blinded by previous success. In the second decline stage there is inaction and denial of risk. In the third stage the crisis is escalating and becomes visible to the Authorities. If decline escalates further into the fourth stage merges are commonly seen as the natural way out. In the fifth and final decline stage the bank is failing.

We find that during financial crises many bank managers feel that they may have no other option than to merge. However, strategic options behind mergers seem to be different during economic recession and boom times. Based on 309 bank mergers during 1990 to 2013, we found that many bank managers gradually lost their confidence concerning their capability of successfully running their banks, therefore choosing to merge. We found that bank mergers are most often associated with bank decline and failure. The largest banking group, i.e. the savings banks group, in the 1980s went on a growth and merger track and failed. The mergers in the savings banks group did not prove to be a recovery recipe from the crisis. The results instead point towards failure and massive value destruction. On the other hand, the mergers producing Nordea can be seen as a result of a successful recovery strategy. However, let us recall that bank mergers often fail e.g. the four largest Finnish banks - UBF, KOP, Postipankki and Skopbank - that existed in 1990 today only exists in the history books. Furthermore, we observed that a loose form of "mergers" like the cooperative bank consolidation in 1997 turned out to be a good recovery recipe.

Bank decline and mergers can be discussed in different contexts (see e.g. Kiefer, 2014; Tri Santoso, 2014). Sinha et al. (2012) as well as Collins (2009) note that having a celebrated CEO may push the institutional culture into the road of decline. It is evident that the role of the management cannot be understated when it comes to running a bank. This is particularly important when the most influential owners might be a diffuse public authority or the depositors of the bank. In the case of the bulk of the bank declines during the 1990s in the Nordic countries, the issue of corporate governance is extremely important. We will use mainly Finnish bank data to create a model for explain bank decline.

One hypothesis that we had was that bank mergers during a decline period would in general follow the same pattern. It does not matter if it is the still ongoing global financial crises, the latest US, UK, Irish or Nordic banking crises. The debtdeflation explanation by Fischer (1933) still seems to be valid. Crises start with growth in the financial sector and indebtedness amongst borrowers, followed by an increase in property prices. Subsequently, the bubble bursts and a financial crisis emerges, hitting the real economy.

In the United States and Europe, rapidly evolving technological changes, deregulation and globalization had in the late 1980s and beginning of the 1990s, as noticed by Amihud and Miller (1998), triggered a wave of bank mergers and consolidation unseen of since the Great Depression. The bank merger wave of the late 1980s and early1990s was followed by a new bank merger wave due to the global financial crises starting with the growth of shadow banking in the USA, followed by the world's largest bankruptcy of Lehman Brothers in 2008. The crisis spread to Europe. In Iceland and Ireland the banking systems collapsed in 2008 and soon all EU countries were hit by the global financial crisis. The banking sector in Finland was no exception from the merger waves of the global financial crisis. Even if the banking sector as a whole remained relatively sound and showing a fairly good profitability 2008-2013.

\subsection{Previous descriptions of decline in banking and bank mergers}

Greenhalgh (1983 p 232) defines decline as a deterioration in the organization's ability to adapt to its environment: "Decline occurs when the organization fails to maintain the adaptiveness of its responses". McKinley, Latham \& Braun (2014 p 90) see decline as a steady downward trend, however they distinguish organizational decline from organizational downsizing: "organizational decline is an involuntary, unintended resource decrease that affects an organization, whereas organizational downsizing is intentional workforce reduction engineered by managers". Collins (2009) again sees decline as partly depending on the management process e.g. in the case of the world's largest bank in the 1980, Bank of America. However, the solution to decline lies not in the simple bromide: "Change or die". Bank of America changed a lot and nearly killed itself. Clearly both internal as well as external factors will affect the decline of a bank. We see bank decline as a process in which a substantial decrease in the banks resource base occurs, over a time period. Often, but not always, the bank decline period is connected to a decline in the economy.

Bank management in a recession period is a difficult task and unfortunately there are no sure 'strategy recipes' available for management dealing with a decline. Weitzel and Jonsson (1989) have, based on earlier research, and introduced a five-stage description of the decline in organizations and the important questions that are associated with each stage. Quite a few studies have been made on the subject of bank performance, and based on international findings we know that there seems to be no evident economies of scale in the banking sector. Contrarily, diseconomies 
of scale have usually been found instead, i.e. larger banks have been found to be more cost inefficient. It could thereby be argued that the informed bank managers are aware that the economies of scale argument are not really a useful argument in favor of bank mergers.

Bank mergers are here defined as a variety of combinations of banks created by different types of contractual arrangements. While, a bank acquisition can be seen as combination of banks where one bank acquires the other bank(s). Depending on the context and the size combination can be seen as forced or volunteered.

What then are the potential reasons for bank mergers? As noticed by Berger et al (1999) the primary motive for consolidation is maximizing shareholder value. The consolidation activities should be geared towards maximizing the value of the existing shareholders or owners. However, in reality it is not value maximization alone that can explain merger decisions. The motives for mergers can be divided into two subgroups, i.e. value maximizing motives and nonvalue maximizing motives.

\begin{tabular}{|c|c|}
\hline \multicolumn{2}{|c|}{ Table 01: Motives behind bank mergers } \\
\hline Value-maximizing motives & Non-value maximizing motives \\
\hline 1. Increasing efficiency & 1. Managerial motives \\
\hline Increasing market power (price settings and availability) & 2. Authorities motives \\
\hline 3. Other value-maximizing motives & 3. Increasing the probability of survival \\
\hline & 4. Other motives \\
\hline
\end{tabular}

A bank can mainly maximize its' value through consolidation by achieving an increased efficiency or by gaining a greater market power. The increasing efficiency arguments usually involve the arguments of economies of scale (larger units can produce the output at a lower price) and economies of scope (advantages by providing a mix of products and services). These two factors are often combined with other potential efficiency gains and then referred to as Xefficiencies. Case studies of US and EU bank mergers and acquisitions indicate that if a better run bank reforms the practices and operations of a less efficient bank, then the bank merger will appear to have the best potential for successful value creation. According to Vander Vennet (1996), large efficient banks tend to acquire small, less efficient banks. However, Piloff and Santomero (1998), notice that the empirical evidence shows that there is in general no significant value effect emerging from bank mergers. Rhoades (1999), who studied bank mergers between fairly equal sized banks, found that the merging banks would usually cut costs. Most cost cutting was made in personnel, data processing systems and operations. However, it is evident that cost cutting alone will not be enough to increase shareholder value or create a successful merger.

Berger et al (1999) notice that the bank mergers that have occurred during the 1990s have dramatically increased the concentration rate. The largest banks may therefore be able to influence the market price and market development. The increased market power argument may also be used to explain the recent mergers between banks and insurance companies. The legal obligations and other non-value maximizing motives behind mergers were probably more important than the value maximizing motives. In situations where the corporate control elements may be relatively weak, i.e. in banks owned by depositors or the government, managers may be able to pursue their own interests. Empire-building may be one of the managerial objectives, which may be pursued in order to gain more personal power and financial compensation. The risk of overpaying for merger activities is evident when the managerial incentives are not in line with the owner incentives. We can also see that the pursuit of growth blinded a lot of Finnish bankers. Hadlock et al. (1999) found in their study of bank mergers and managerial incentives that banks in which managers hold a substantial share of the stock are less likely to be acquired A merger is not only an intentional economic and technical operation. It also includes elements of a strategic, cultural and mental operation of the CEOs. Kangas (2006) found that the bank Authorities` opinions were important when it came to influence bank managers` decisions to merge.

The Authorities involvement in bank mergers and acquisitions (M\&A) mainly emerges from three needs:

1. Prevention of financial failures.

2. Regulation of banks e.g. preventing banks from becoming too big to fail.

3. Government ownership, creating a need for "political correctness". Sometimes public ownership is seen as a good thing and sometimes not.

It is notable, that the Authorities' motives and incentives have seldom been studied in-depth, despite that fact that the European Union is about to create a banking union, and there is an institutional pressure for mergers.

The issue of bank mergers is complex. Firstly, there is no single, unambiguous measure to correctly estimate the merger effects on the banks or society. Secondly, the interpretation of obtained data is a process that involves the human factor. And we know that the capability of all humans is limited. Despite this it is evident, as argued by Tainio et al (1991), that the categories of environment, strategy and organizational structure can be expected to cover the major determinants of 
performance. Tainio et al (1991), who studied 79 Finnish savings banks during the beginning of the 1980s, found that bank performance could not be described by a single criterion. Instead, they stress the complexity of performance, which is influenced both by the context and the decision-makers. Their result follows in the footsteps of Lenz (1981), who argues that there is no universal cause-effect relationship from the explanatory variable studies to explain the organizational performance. Instead, there seems to be an interaction between time and space, which may explain the puzzle of performance. At one point in time a specific action may lead towards success, while the same action at another point of time may lead towards disaster.

\subsection{Bank mergers and acquisitions in Finland 1990-2013}

The data in this study consist of the Finnish banking market 1990-2013. During this period the bank mergers and other consolidation activities were analyzed. In all 309 bank mergers and 20 acquisitions occurred. The great Finnish Depression 1991-1995 is affecting the bank market mergers for a long time. During the merger period 1990 to 2000 there are 220 pure bank mergers (138 savings bank mergers and 77 cooperative bank mergers and 5 commercial bank merges), 5 bank acquisitions and 2 banks were taken over by the Authorities and partly sold and thereafter run down. On top of that 252 cooperative banks chose 1.7.1997 to consolidate their balance sheets. This not a merger per se even if the financial institutions chose to start calculating the solvency level as one unit. Only 44 cooperative banks remained outside the consolidation and formed a new bank group, The Local Cooperative Banks (Paikallisosuuspankit). The same had happened in the savings banks group in 1992 when the 44 most profitable and solid banks chose not to merge.

The bank market started to recover during the late 1990s and in 1999 to 2007 the number of banks remained stable at 338 , even if the number of financial institutions increased, due to creation of asset management companies. In 2009 the global financial crisis hits Finland with a GDP decline of $-8.5 \%$ and the number of monetary financial institutions decreases from 360 in 2008 to 298 in 2013. (Source: ECB 2014) In 2008-13 3 banks went bankrupt and one was liquidated and the 72 were merged. Thus we can talk about a new merger wave due to the global financial crisis.

The data used in this study is based on several sources: we have used bookkeeping data, interviews with bank managers and surveys among bank managers. One of the researchers was also a bank manager, who was able to follow the process from within the banking sector. He kept a daily diary of what happened concerning bank management during the years of bank decline. Thus we have used a triangular research method in order to come up with our observations.

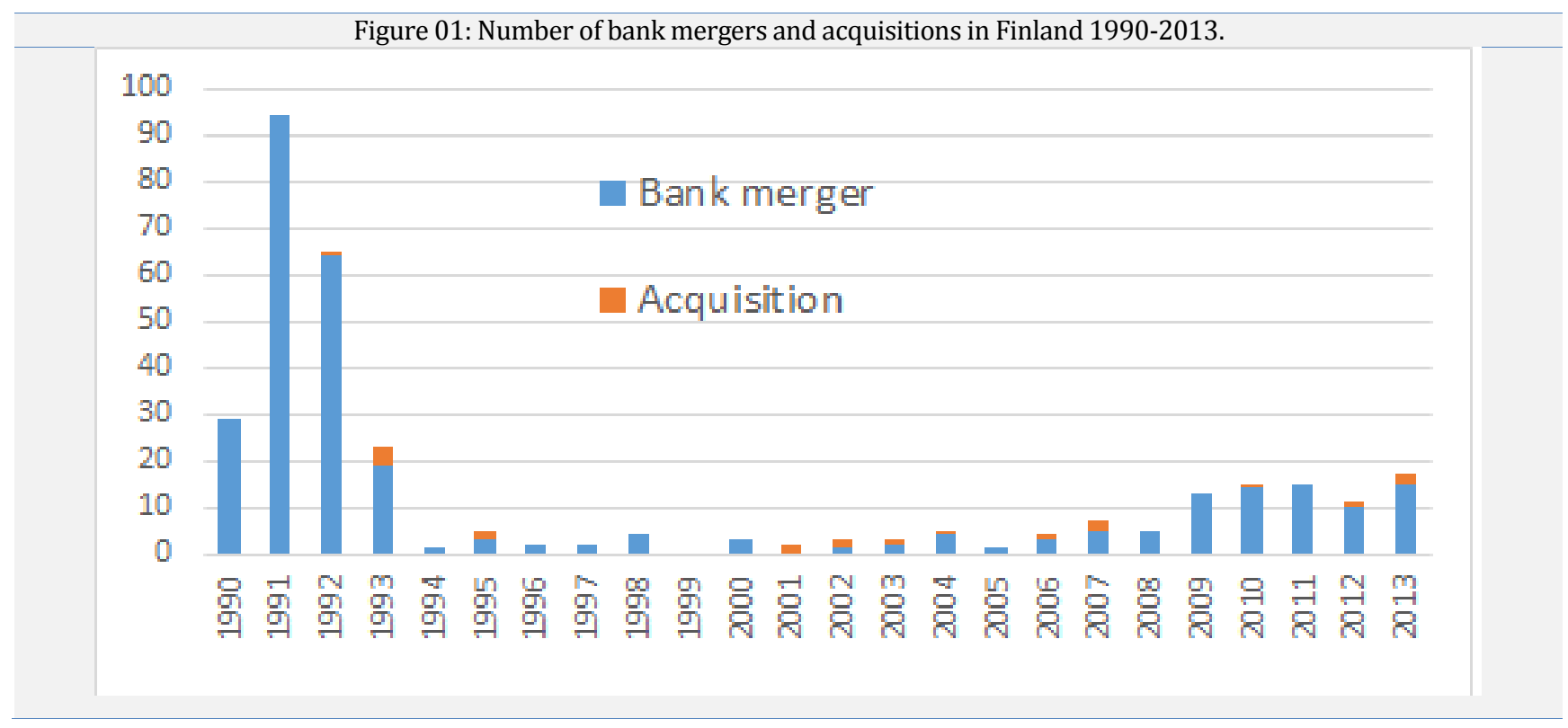

\subsection{Remarks concerning mergers as a recovery recipe}

The mergers during the period 1990-2013 are particularly due to crises. We can distinguish two merger waves from the data. One emerging from the great Finnish depression 1991-95 and focusing mainly around the savings banks group, and another merger wave relating to the global financial crisis starting from 2008. Thus both merger waves can be related to external economic crisis. In general bank crises can be divided into internally and externally generated crises. We find that particularly in the case of the savings banks mergers 1990-1992 the combination of negative externally and internally produced causes, were devastating. Bad bank management and bad times in combination with bad policies by the authorities created a merger boom never seen before. 
The Finnish banking industry is shrinking during the period 1990-2000 and reporting an aggregated net loss of 39.7 Billion marks or about 6\% of total assets (Source: Statistics Finland, 1990-2001). Solttila and Vihriälä (1994) find that it is the fast growth of the bank lending in the years before the crisis that can explain this negative impact on the performance of the banking industry. The faster the growth was in the late 1980s, the higher was the rate of nonperforming assets.

\subsection{The case of the mergers in the savings banks group}

At the beginning of the 1990s, the merger process is particularly focused around the savings banks, which in 1990 was the largest banking group in Finland. During 1990-2 138 savings banks will merge merger. A growth and merger process in the Skopbank Group had been revitalized in the 1980s, and usually when a savings bank was facing financial difficulties it was merged into a larger savings bank. However, in the early 1990s the largest savings banks were facing severe financial distress. Thereby the picture had to change. The small profitable savings banks did not have sufficient resources to bail out the often badly run larger savings banks.

On top of this the Skopbank, which was the central bank for the savings banks, started to fail. It was owned and controlled by the savings banks through the Skopbank K share (91.7\% of the votes), while Skopbank A shares were listed on the Helsinki Stock Exchange. However, on the 19 th of September 1991 the Bank of Finland decided to take control over Skopbank, due to an evident possibility of a failure. This was done through an external equity input by Scopulus (i.e. the Bank of Finland), which implied that the control of Skopbank was in the hands of the authorities.

The "vitalization" of the merger process among the savings banks proved to misfire. During the latter parts of the 1980s, the thought was to create 40 larger regional savings banks. However, the result turned out to be a sense of mistrust in the Skopbank group. During the first part of the 1980s, the Savings bank group was already the largest banking group. However, the savings banks were in some circles regarded as rural and slow-moving, while Skopbank, on the other hand, was seen as fairly small commercial banks, since the corporate banking was concentrated around the two big commercial banks; UBF and KOP. In 1985 a new aggressive strategy was launched, mainly by Skopbank, with the ambition that the Skopbank group should be the leading bank in all fields of the Finnish credit market: the best bank group on the real-estate market, equity market, corporate banking etc. Kjellman (1997) finds that this high ambition is, according to the CEOs of the banks that have survived, more of a contributing factor towards the crisis than what the CEOs of the failed banks argue. This finding may be explained by the fact that the banks that survived in general were more critical towards the growth-merger strategy supported by Skopbank and the Finnish Savings Banks Association.

In the beginning of 1992, the embryo to the Savings Bank of Finland (SBF) had been formed, and in June 1992 the Government Guarantee Fund (GGF) decided to support the merger of the savings banks into a new bank (SBF), which would be controlled by the government. An extensive cost reduction plan was launched and by October 1993 a quarter of the staff had been laid off, and 160 branches had been closed. However, on the 22nd of October, 1993 the Finnish Government, on the recommendation of the Government Guarantee Fund, decided to sell the sound parts of SBF in equal parts to the four major bank groups in Finland, i.e. the Okobank Group, the state owned Postipankki, UBF and KOP. The non-performing assets of the SBF were transferred to the government owned asset holding company, Arsenal Ltd. The four buying banks were also given the option to transfer additional problem credits to Arsenal Ltd. Thereby, the government carried the entire credit risk. Kjellman (1997) noticed that this arrangement was, according to 126 savings banks managers, an important factor behind the problems.

When we discussed with bank managers of savings banks we notice an evident sense that the choice to merge was a mistake. And many CEOs point to the fact that there would have been many more banks and a more stable banking industry in Finland today if they only had not merged. Another interesting fact is that the CEOs in many cases are blaming themselves for the mistakes that were made. To sum up, the mergers in the savings banks group did not prove to be a recovery recipe from the crisis. The results instead point towards a big failure and massive value destruction. Only 40 relatively small and sound savings banks survived.

\subsection{The case of Nordea}

The case of the merger of the two largest Finnish banks Kansallis-Osake-Pankki (KOP) and Unitas (i.e. Union Bank of Finland, UBF) can be seen as a result of the banking crisis. Both the commercial banks that were of about the same size had been showing highly negative results during the last four years before the merger decision. The financial situation in both banks was therefore strained. The Finnish government had conducted a capital injection into the banking system in 1992 and was thereby the largest single owner in both banks. However, most bankers argued that KOP, in particular, was facing evident financial distress. KOP had shown a loss of 1.8 Billion marks in 1994 and no improvements were expected for 1995. On the $14^{\text {th }}$ of February the merger treaty was signed and on the $2^{\text {nd }}$ of June, 1995 Merita Bank was officially starting its operations. 
The arguments: put forward by the CEO of Unitas (and later Merita) Vesa Vainio (1995) in favor of the merger was in brief: 1) that the increased global competition had created a merger pressure, 2) that the cost cuts were potentially very significant, and 3) that the new Merita Bank would be able to create positive synergy effects. Similar arguments were put forward by the CEO of KOP. Occasionally, arguments to create a large and strong Finnish bank were used. However, the real reason behind the merger was most likely the poor results during the years before the merger. Both banks were struggling and additional cost cutting was to be expected.

The outcome of the Merita merger was that the cost cutting process was further accentuated. The plan was to decrease the staff by one-third. The staff, which was about 18,100 before the merger, was planned to be 12,100 by 1997. During the merger year 1995, the staff was reduced by 3,478 work years, and by the end of 1997 , there were 10,950 employed. The number of branch offices was planned to be reduced from 775 to 500 . However, even this goal was exceeded. By 1997 only 434 branch offices remained. The reduction would be further accentuated during 1998 due to the merger with the Swedish bank, Nordbanken. However, significant cost cutting was made and the cost cutting goals were even exceeded. The Merita merger can thereby be seen as a merger where the bank managers are using the merger to rationalize the banks' activities. In fact, the other megamerger of the early $1990 \mathrm{~s}$, i.e. SBF, was also most efficient in cutting staff and activities. However, the paradox is that the mergers will, in the short run, increase costs.

However, the largest merger is still to come. In 1997 it was called the "largest" cross border merger between two equal banks, i.e. the merger between the Finnish Merita Bank and the Swedish Nordbanken. A new era of Nordic banking is starting to accelerate. Both Merita and Nordbanken had identified the Nordic countries and the Baltic Sea area as their home market before the merger. And they were, like many other Nordic banks, looking for opportunities in neighboring countries. In Finland, the Swedish bank Handelsbanken had already opened several branch offices and bought the sound parts of Skopbank, which was put into liquidation.

The argument put forward in favor of the MeritaNordbanken merger was the need to create a large Nordic bank that could compete with the large banks in the world. Furthermore, the CEO of Nordbanken, Hans Dahlborg, stressed the creation of shareholder value, a new financial situation and a long term perspective. He also mentioned the opportunity to use "best practice" when rationalizing the new bank. When cutting costs, the best parts of both banks would be used. CEO Vesa Vainio of Merita also mentioned the fact that the Finnish bank would gain a strong foothold in Sweden. Now several years after the merger we can see that the Finnish part Merita has been the smaller of the two merging partners, e.g. the headquarters that was initially put in Helsinki, Finland has been moved to Stockholm, Sweden. Thereby, one could argue that about half of the Finnish banking industry is highly dependent on the decisions made in Stockholm, Sweden. MeritaNordbanken has, during the year 2000, bought a Norwegian bank Kreditkassen, and decided to merge with a large Danish bank, Unidanmark 1998, which gave the Danish owners 30\% ownership in the Bank. Thus, further eroding the Finnish influence in the bank. In 2000 the Norwegian Christiania Bank og Kreditkasse was merged into the bank. And in 2001 the Swedish Postgirot Bank was acquired and the name changed to Nordea (cf Söderberg and Vaara, 2003). We can only speculate on the real reasons behind the MeritaNordbanken merger. However, it seems most likely that some of the managers - who were not real financial stakeholders (only owning a few shares) - were dreaming about building a Nordic bank empire. To sum up the merger process producing Nordea can be seen as a successful recovery strategy.

\subsection{The rest of the merging banks in the first merger wave}

After five years of negative results in the banking sector (1991-1995) the concentration rate in the Finnish banking industry had increased. Less than one fourth of the savings banks survived, the two largest commercial banks merged and the cooperative banks were drawn closer into the Okobank cooperation. The consolidation activities after the crisis years also appear to have been driven by the economic depression. Good examples of this is the creation of Leonia 1998 from government owned financial institutions, as well as the Sampo-Leonia merger 2000. The effect of the banking crisis is that even 9 years after the banking crisis had started the government is not willing to put more money into the banking system. Instead the state owned Leonia bank was merged with an insurance company Sampo.

One of the most genius banking events in the Finnish history occurs in 1997 when most of cooperative banks decided to consolidate their balance sheets. This activity is not considered a merger because the independent cooperative banks still have their own statutes. In 1997 the Okobank Group consolidation concerned 298 independent cooperative banks. Of these banks 43 solid and profitable banks decided to leave the group and form a new bank group. It is clear the consolidation process was driven by bad results inside the consolidating institutions. In general, the best run cooperative banks opted to leave, while the large cooperative banks that had depleted their financial resources during the hard years, did not have the choice to be able to leave. Old obligations and a lack of funds made it close to impossible to continue with independent banking for most of the cooperative banks. To sum 
up a loose form of merger like the cooperative consolidation, which allows to banks to remain independent however, calculate their solvency on a group level, seems to be a good recovery recipe.

Kjellman and Nordman (2000) analyzed Finnish bank mergers and acquisitions from 1990 to 1995. During these years 207 bank mergers occurred (138 Savings banks, 67 cooperative banks and 2 commercial banks) creating 60 "new" banks. The results of these mergers were analyzed during the time period two years after and before the mergers. The findings indicate that the Finnish bank mergers 1990-1995 are not reducing but increasing costs; after the merger the operating costs were increasing (excluding the interest rate cost). The potential explanation for the increased cost after the merger is that there are costs associated with merger activities, e.g. laying off personnel is often initially costing (compensation for leaving, early retirement plans etc.), harmonizing the banking cultures, making computer systems compatible, and increased shown credit losses. The findings also indicate that the credit losses are significantly higher the year after the merger, than 2 years before the merger occurs.

\subsection{The global financial crises triggered a new bank merger wave 2008-13}

The current merger wave during (2008-2013) consists of 72 bank mergers, and more is on the way. The reasons behind these bank mergers relate to the economic downturn and increased global connectivity. The Finnish GDP shrank in 2009, 2012, 2013 and most likely in 2014, while the European Central Bank pushed the market interest levels down to record low levels. Thereby, affecting the Finnish banking market and created a new wave of mergers. While we interviewed CEOs of local banks we noticed that even the bankruptcy of Lehman Brothers carried its wings to the most rural parts of Finland. Many banks had owned commercial papers issued by Lehman Brothers and lost money. However, the "spiritual" effect steaming from the global financial crisis on the bank CEOs was even greater. A spirit of depression and caution about the future could be observed among the bank managers. We found that mergers have been used by the bank managers as a defensive weapon. The merging bank managers seem to have become unsure about their own capabilities and their banks future, and opted to merge. Many small bankers seem to have become afraid of the work load that the new European banking regulation will cause. The increased regulation and control of the banks require more work and it increases the bank costs.

\subsection{A model of bank decline and bank merges}

We have drawn on the work of Collins (2009) and Weitzel and Jonsson (1989) and adapted their models to decline in banking. We argue that there are six stages in the decline process of banks. The first pre-stage of bank decline is in fact a little contradictory, because we found a period of rapid growth before the decline phase starts. Growth seems to breed the seeds of decline in the financial industry. This growth period may also include bank mergers. However, let us begin by noticing that growth mergers are different from decline mergers. There are different dynamics and motives in growth and in decline. During a growth stage of the banking market many banks are looking for opportunities to expand. Then the banks may be buying market shares through merges and acquisitions, while the bank mergers during a decline period may be more focused around survival of the bank.

In brief the model can by summarized as follows. In the initial pre-decline stage growth seems to breed the seeds of decline. In the first real decline stage the bank management becomes blinded by previous success. In the second decline stage there is inaction and denial of risk. In the third stage the crisis is escalating and becomes visible also to the Authorities. If decline escalates further into the fourth stage merges are commonly seen as the natural way out. In the fifth and final decline stage the banks are failing.

\section{Pre-stage: The Growth stage}

Growth seems to breed decline in banking. Before the decline stages all major banking crises have been triggered by a growth phrase in the financial industry. This growth may steam from different sources e.g. deregulation, general indebtedness and creation of a "shadow banking" market. We find that a few years of more than normal growth seems to breed the way towards decline. In particular if the bankers start to talk about a new way of conducting banking to gain more market share. Then the alarm bells should be ringing. The managerial implication in this stage is that bank growth will cause the banks risk exposure to increase. Thus, one should be cautious to expand to fast into potentially unknown territories and customer groups. Based on our evidence, success breeds failure. As one of our sources said about the spirit in Skopbank: "We're so great, so just let us just agree on one thing and that is to never be poor again". The undisciplined pursuit of more scale, more growth, more of whatever those in power see as "success" leads right to the following stage.

Figure 02: Decline in a bank. The real performance of the bank is usually first improving and after that gradually deterring. The figure is based on Weitzel and Jonsson (1989) and Collins (2009), however adapted to suit the financial sector. 


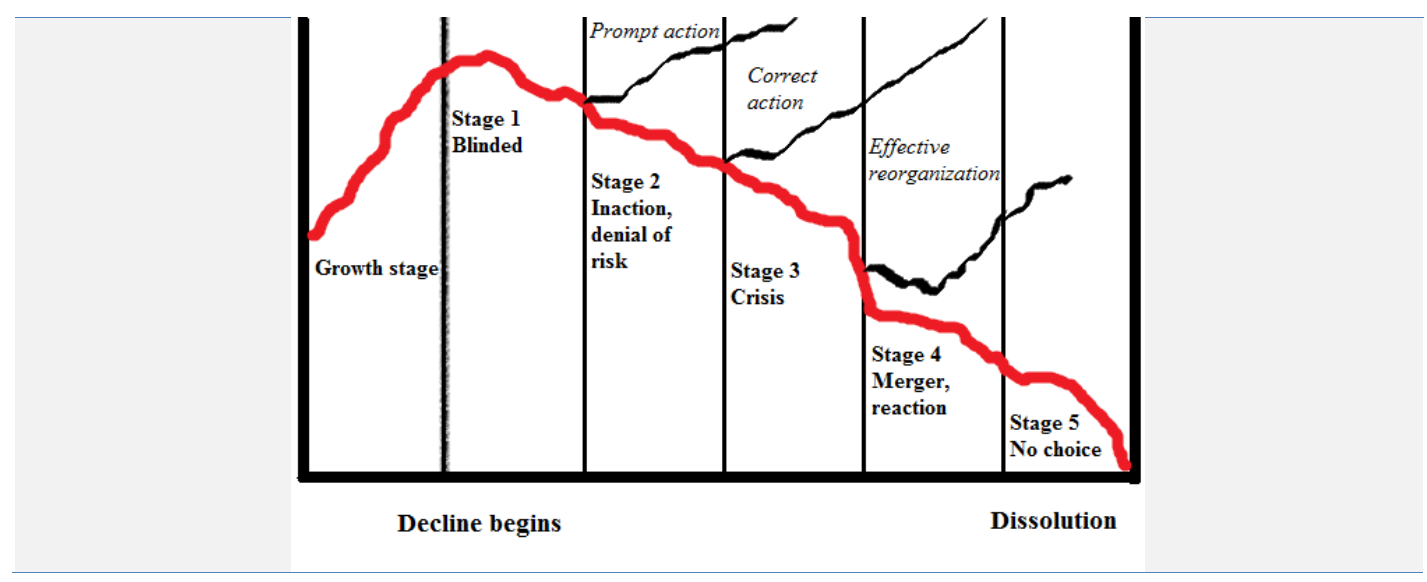

Stage 1: The blinded stage

Great banks can become insulated by success; accumulated momentum can carry an enterprise forward for a while, even if its bankers make poor decisions. Military discipline with arrogant leaders is a blinding cocktail. This was typical in the case of Skopbank, which had experienced a strong growth case during the 1980s. Success made the management of both Skokbank and KOP arrogant and too brave. Good examples of the arrogance and complancement can be found in Tainio et al (2002). The first mistake was that the Board of Skopbank had delegated the power to young managers. The initial success of the young management breaded the failure of Skopbank. They were talking about a new type of banking. And one lesson to be learned is that when that is happening, things may start to go wrong. Stage 1 usually kicks in when people become arrogant, regarding success virtually as an entitlement, and they lose sight of the true underlying factors that created success in the first place. The casino economy of the late 1980s blinded most of the larger banks in Finland. Luck and chance play a role in many successful outcomes. Many bank managers failed to acknowledge the role luck may had played in their success and thereby overestimated their own merit and capabilities.

Many CEOs just does not seem to see the evident. If the times are good and the customers are borrowing too much, it will lead to indebtedness and problems. It is not so hard to see that too rapid bank growth may cause future problems. Nor is it hard to see that derivative contracts and sophisticated financial products may cause banks to go under. It is not only the oldest and respected British bank, Barings banks that have dissolved due to derivative contracts. In Finland the failure of Helsingin Osakepankki (currency option speculation 1985) and the state owned Postipankki (a swap loss 1995 in the USA) are due to miscalculated speculations. You just might find yourself surprised and unprepared when you wake up to discover your vulnerabilities too late.

The managerial implication in this blinded stage is that bank growth has caused the banks risk exposure to increase. At this stage the previous growth strategy of the bank should be questioned and reevaluated. Very few organizations can grow forever.

Stage 2: Denial of risk and inaction to maintain or get needed own capital

Banks in Stage 2 stray from the disciplined creativity that led them to greatness in the first place, making undisciplined leaps into areas where they cannot be great, often do to the simple fact that they have very little experience from the new areas. A good example of this is the internationalization of the Finnish commercial bank in the late 1980s. The banks expanded to UK, Luxemburg and the USA and tried to create new business opportunities. The problem was in these countries the good customers were already taken, and expansion into unknown areas was very risky. Virtually no actions were made to maintain a sufficient level of own capital, nor to get rid of bad customers nor reducing the risk exposure. When we look at the savings banks and Skopbank, we find many examples of denial of risks. When a bank grows beyond its core business it has set itself up for potential problems. Those in power start to blame external factors for setbacks rather than accept responsibility. Examples of bank manager behavior in this stage could be meltdown of the bank's team spirit and internal fighting, which keeps the managers busy. The vigorous, fact-based dialogue that characterizes high-performance teams dwindles or disappears altogether. Taking action inconsistent with your core values is common and increasing the risks.

The managerial implication of this stage is that the bank is now in decline and prompt actions are needed to turn the development around. A natural strategy is to first identify and examine the risk exposures and then deal with them. Inaction and denial of risk exposures will lead to a severe crisis situation for the bank. The inaction to not see this and react will gradually lead the bank towards stage 3.

Stage 3: Crisis

As banks move into the crisis stage, internal warning signs begin to mount. As Collins (2009) noted external results may remain strong enough to "explain away" disturbing data or to suggest that the difficulties are "temporary" or 
"cyclic" or "not that bad," and "nothing is fundamentally wrong." At this stage intentional downsizing is a hard but typical option for the potential turnaround banks. "In reality assets can be sold off at a bargain price or the bank's real estate holdings can be "written upwards" in order to increase the shown own funds." Kangas (2006) noted that not even at this stage some managers gasp the danger. In fact it is sometimes hard to see hidden problems like real value losses in assets, derivative exposures and potential counterpart problems. Real performance results may either be hidden in off balance transactions or not reported properly in the balance sheets. The bank managers start to blame external factors for setbacks rather than dealing with the problems at hand. The vigorous, fact-based dialogue that characterizes high-performance teams dwindles or disappears altogether.

At this stage also the Authorities and politicians starts to realize that they may be facing a banking crisis and potential costs for the public sector. Banks may need to be rescued by the government. The stability of the entire economy may be at stake and the politicians feel a need to act. In Finland the typical solution presented by the Authorities was to urge the crisis banks to merge both in the 1990s and after 2008.

The managerial implication in the crisis stage is to find turnaround solutions for the bank. Potential solutions are cost cuts, increase capital inflow, reorganization, increase solvency, customer driven innovations \& services, mergers and in special cases even acquisitions. As noticed by Tourish and Harigie (2012) many bank managers became influenced by the behavior of "significant" others, and these bankers found themselves to become passive observers of events. A real danger is inaction in combination with starting to imitate and believe in big and loud bank players. When the bank is in the crisis stage, it is important not to rely on others to solve your problems, but instead try to solve them yourself. Good bank management at least includes the element of being able to solve your own problems, while an imitating, passive and on others relying strategy can be linked to bad bank management.

Stage 4: Bank mergers as a recovery recipe

The potential of a disaster is visible to all informed in the bank. The critical question is: what can the CEO and the boards do? A quick salvation in the form of e.g. a merger may seem appealing? In Finland bank merges were the most common crisis response to a severe crisis situation. When the pressure from the Authorities, bank owners and depositors are increasing our findings indicate that a bank merger was considered an appealing solution. If the bank merged with another bank the unpleasant reconstruction work could be moved over to another part. Thereby the responsibility of the bank managers and board could be shifted away.

We found that bank managers at this point in reality may have lost a lot of their room to maneuver. In fact further cost cutting may not be enough, and during a decline phase it usually is harder to receive additional funding in order to increase the solvency level. This in most cases leaves the bank manager with no other real option than to merge or declare bankruptcy. Kangas (2006) argues that when the bank managers' room to maneuver decreases and decreases, then finally the mental process will lead to a situation that the bank manager feels like he has no room to maneuver. We argue that if the bank managers found themselves cornered with the options to leave the bank, declare bankruptcy or try to find a buyer, or merge with another financial institution, then the option would be to merge. Faced with two real options, i.e. to merge or to declare bankruptcy, the bankers chose to merge. Thereby, we argue that this no-way out argument may be used to explain most of the Finnish bank mergers from 1990 to 1997 and 2008-13. The "satisfactory" solution for the latent financial problems was by many CEOs seen to be, to merge. Thereby the profitability problem could be dealt with in an acceptable way. The required shake-up of the bank did not call for a declaration of mistakes made by the CEO. The layoffs could be blamed on the merger, and the CEO could continue as a bank manager. An interesting observation that we make is that in Finland "all" banks involved in a merger process seem to have potential solvency problems.

The managerial implication for this stage is that a merger can be a potential crisis response, however, it most likely also means the end of the bank. However, let us recall that a bank manager cannot decide about a bank merger alone, also the owners and the authorities must agree to the deal.

Stage 5: No choice, belly up,..., or merge?

In the fifth stage the bank managers have realized that the bank cannot be saved by the bank itself, but the preferred and often only way out is to rely on the authorities. To start playing the game for receiving help from the central bank or the tax payers is on. The accumulated setbacks and expensive false starts erode financial strength and individual spirit to such an extent that a banker abandons all hope of building a future. In some cases the bank's leader just sells out like in the case of the mergers of the state owned financial intuitions creating the state owned Leonia bank; and in the most extreme cases the bank simply goes belly up, like in the case of Skopbank or the two Icelandic banks' Finnish branches 2008. All in all however, only 3 small banks goes bank bankrupt 1990-2013. All the other declining banks were either merged or taken over by the authorities. In stage banks may be forced by the Authorities to merge like in the case of the Savings Bank in Finland. Thus, the bank merges in this dissolving crisis stage can be seen as no other way out solutions. 
When we interviewed bank CEOs we became convinced that the basic decline model as given in figure 2 gave a good description of what had happened. However, there was one problem. The different roles of the bank manager in pursuit of turnaround and the personal qualities of the CEO are not stressed sufficiently. We became convinced that a model which would explain bank consolidation should stress the activities of the bank CEOs. Some CEOs were able to create opportunities for turnaround, while other CEOs were not capable of corrective actions during the decline process.

We also have to recall that the bank managers are socially influenced individuals. They live in their current life space, and have experienced the past as well as have aspirations for the future of themselves and the bank. These aspirations will be one factor among many other potential factors that will explain how the bank manager will lead his bank in decline. If the bank has got to a truly critical stage then in reality the bank manager only has got two real potential choices: To merge or declare failure. Most bank managers will opt for a merger process instead of admitting that, they believe, that the banks operations cannot continue.

Finally, it can be noticed that the consolidation activities inside the EU and the USA show no sign of stopping. Since the large seem to get larger, we can most likely expect more mergers and acquisitions in the future. However, let us recall that bank mergers often fail e.g. the four largest Finnish banks - UBF, KOP, Postipankki and Skopbank - that existed in1990 today only exists in the history books.

\subsection{Conclusion and policy implications}

We have created a model concerning bank decline. In banking we argue that decline cannot be understood without looking at growth before decline. Based on 309 bank mergers during 1990 to 2013, we found that bank managers in many cases gradually lost their confidence concerning their capability of successfully running their banks, therefor opting for a bank merger. The reasons behind merges seem to be time and context dependent. In our model of bank decline we see the role of the bank manager as crucial. The major reasons behind the Finnish bank merger waves seem to be bad bank management and real economic crisis, which was caused by the Finnish depression of the 1990s as well as the global financial crisis starting in 2008.

After a bank growth phase, some banker became blinded and led their banks into a crisis phase. Faced with two perceived options, i.e. to merge or to declare "bankruptcy", the bankers often chose to merge. Thereby, we argue that this no-way out argument may be used to explain most of the Finnish bank mergers from 1990 to 2000 and 2008-13. The "satisfactory" solution for the latent financial problems was by many CEOs seen to be, to merge. Thereby the profitability problem could be dealt with in an acceptable way. The required shake-up of the bank did not call for a declaration of mistakes made by the CEO. The layoffs could be blamed on the merger, and the CEO could continue as a bank manager. The board members were given an excuse for retirement, or handed the argument that they were doing something about the profitability problem. The personnel that were not laid-off were promised a future in the new banking organization and thereby some of their lost trust could be regained. The customers were promised a larger (however leaner) bank that certainly offered increased security and improved service capability. In fact the choice to enter into a merger seems to be appealing at least partly to all of the involved stakeholders.

Why do so many bank mergers fail to generate recovery? During the period 1990-2000 the mergers were particularly due to the banking crisis. In fact, the banking industry is, during this period, is reporting a net loss. We are still today feeling the effects of the banking crisis of the 1990s. However, we also find that managerial incentives and empire building seem to have been a triggering factor behind some mergers. We cannot see that shareholder value creation would have been the main motivating force behind the mergers of the 1990s, even if the argument has been used by e.g. Nordea. Today it seems like many bankers seem to have become afraid of the work load that the new European banking regulation will cause. The increased regulation and control of the banks requires more work and increases the bank costs, thus this fair is creating more mergers and bigger banks.

We found that in almost all of the cases of merging banks, the bank managers had started to lose their confidence in being able to maintain the CEO position or the bank as independent unit. Even if the absolute bulk of the bank mergers in the 1990s and from 2008 and forwards in Finland cannot be characterized as successful mergers, it is still not wise to condemn a merger strategy. Mergers have been useful as a mean for continuation of banking activity. However, the Finnish evidence points to the fact that banks that don't merge will perform better than banks that are involved in merger processes.

One policy conclusion is that we need to be alert when the banks become strongly growth-driven. The lesson for bankers, owners, depositors and Authorities is that rapid growth in banking seems to breed failure. And this we should remember. Another policy implication is that bank mergers are not a universal panacea for solving decline problems. When the mergers occur it is often too late. 


\section{References}

Amihud Y., Miller G., 1998. Bank mergers \& acquisitions. Kluwer Academic Publisher, Dordrecht. http://dx.doi.org/10.1007/978-1-4757-2799-9

Berger A.L., Demsetz R.S., Strahan, P.E., 1999. The consolidation of the financial service industry: Causes, consequences, and implications for the future. Journal of Banking and Finance, 23(2):135-194. http://dx.doi.org/10.1016/S0378-4266(98)00125-3

Collins, J., 2009. How the mighty fall and why some companies never give in. New York, USA. Harper Collins Publishers Inc.

European Central Bank (2014) Statistical data warehouse http://sdw.ecb.int/browseChart.do?REF_AREA $=152 \&$ type $=\& M F I \_L I S T=102 \&$ node $=4586742 \& \mathrm{q}=\& \mathrm{sfl} 2=4 \& S$ ERIES_KEY=187.MFI.M.FI.102.T.1\&DATASET $=0 \& s f l 3=4 \&$ trans $=$ AF Accessed 16.3.2014

Fisher, I.,1933. The debt-deflation theory of great depressions, Econometrica, October, 337-357. http://dx.doi.org/10.2307/1907327

Greenhalgh L., 1983. Organizational decline, In Samule B. Bachanach (ed.) Research in the sociology of organizations, Greenwich, CT: JAI Press, 2:231-278.

Hadlock C.J., Houston J.F., Ryngaert M., 1999. The role of managerial incentives in bank acquisitions. Journal of Banking and Finance, 23(2-4), 221-249. http://dx.doi.org/10.1016/S0378-4266(98)00092-2Hiilamo H., 1995. SKOP lyhyt historia, WSOY, Juva.

Kangas T., 2006. Suomen pankkikriisin alueellinen ulottuvuus: Esseitä paikallisista toimijoista ja toteuttajista. PhD Thesis. Helsinki School of Economics, Acta Universitatis Oeconomicae Helsingiensis, Helsinki.

Kiefer M. V., 2014. Bank failures and mergers in Turkey: 1992-2014. International Journal of Finance and Banking, 1(3): 45-64.

Kjellman A., 1996. What can we learn from the Finnish banking crisis? The case of the failures in the savings bank sector, Meddelanden från Ekonomisk-Statsvetenskapliga Fakulteten vid Åbo Akademi A:420, Turku.

Kjellman A., 1997. Essays on performance and financing decisions during the 1990s recession in Finland. PhD Thesis. Åbo Akademi University Press, Turku.

Kjellman A., Nordman M., 2000. Strategies behind and effects of bank mergers in Finland, Meddelanden från Ekonomisk-statsvetenskapliga Fakulteten vid Åbo Akademi, A:517.

Lenz R., 1981. Determinants of organizational performance: An interdisciplinary review, Strategic Management Journal, 2(2): 131-154. http://dx.doi.org/10.1002/smj.4250020204

McKinley W., Latham S., Braun M., 2014. Organizational decline and innovation: Turnarounds and downward spirals, Academy of Management Review, 39(1): 86-110. http://dx.doi.org/10.5465/amr.2011.0356Pietilä, AP., 1995. Pankkikirja, Helsinki, Art House.

Piloff S.J., Satomero A.M., 1997. The value effect of bank mergers and acquisitions. Published in Amihud, Y. and Miller G., eds. 1997. Bank Mergers \& Acquisitions. Dordrecht, Kluwer Academic Publisher.

Rhoades S.A., 1999. The efficiency effects of bank mergers: An overview of case studies of nine mergers. Journal of Banking and Finance, 22(2-4):273-291.

Saari M., 1992. Minä Christopher Wegelius. Jyväskylä, Gummerus.

Santoso T. R., Hartono M., Agung Prabowo M., Riyanto G., Eferin S., Tjiamudjaja Y., 2014. The arena of multiinterest, governance and fraud - a critical review of BC bailout. International Journal of Finance and Banking, 1(2):2535.

Solttila, H., Vihriälä, V., 1994. Finnish banks' problem assets: Result of unfortunate asset structure or too rapid growth, Bank of Finland Discussion Papers 23/94.

Söderberg, A-M.,Vaara, E., 2003 (Eds.). Merging across borders. People, cultures and politics. Copenhagen Business School Press. Copenhagen.

Tainio, R., Korhonen P.J., Santalainen, T.J., 1991. In search of explanation for bank performance - Some Finnish data, Organization Studies, 12(3): 425-450. http://dx.doi.org/10.1177/017084069101200305

Tainio R., Santalainen T., Sarvikivi K., 1991. Organizational changes in a bank group: The merger process and its generative mechanisms, Scandinavian Journal of Management, 7(3): 191-203. http://dx.doi.org/10.1016/0956-5221(91)90033-W

Tourish D., Hargie 0., 2012. Metaphors of failure and the failures of metaphor: A critical study of root metaphors used by bankers in explaining the banking crisis. Organization Studies 33 (8): 1045-1069. http://dx.doi.org/10.1177/0170840612453528

Weitzel W., Jonsson, E., 1989. Decline in organizations: A literature integration and extension. Administrative Science Quarterly, 34:91-109. http://dx.doi.org/10.2307/2392987

Vainio V., 1995. Konkurrensen omvälver bankmarknaden, Unitas 1:3.

Vander Vennet R., 1996. The effects of mergers and acquisitions on the efficiency and profitability of EC credit institutions. Journal of Banking and Finance, 20(9):1531-1558. http://dx.doi.org/10.1016/S03784266(96)00014-3

Vihriälä V., 1993. Suomen pankkikriisi - Mitä opimme? The Finnish Economic Journal, 4:581-589. 